\title{
The Influence of Cooperative Group Investigation on Student's Learning Result in Natural Science Subject for Grade VIII in Kota Komba East Manggarai
}

\author{
Yosef Frina Demezt ${ }^{1, a^{*}}$, Siti Masitoh $1, b$, Andi Mariono ${ }^{1, c}$ \\ ${ }^{1}$ Master Degree Program of Educational Technology, State University of Surabaya, Surabaya, Indonesia \\ yosef17070905001@mhs.unesa.ac.id \\ ${ }^{*}$ Corresponding Author \\ Whatsapp number: [+6282331438232]
}

How to Cite: Demezt, Y., F., Masitoh, S., Mariono, A. (2019). The Influence of Cooperative Group Investigation on Student's Learning Result in Natural Science Subject for Grade VIII in Kota Komba East Manggarai. International Journal for Educational and Vocational Studies, 1 (8), 893-897. DOI: https://doi.org/10.29103/ijevs.v1i8.2253

\section{ARTICLE HISTORY}

Received: 27 August 2019

Revised: 13 October 2019

Accepted: 5 November 2019

\section{KEYWORDS}

Cooperative Group Investigation; Learning Results;

\begin{abstract}
The study aims to find out the influence of Cooperative Group Investigation on the student's learning result in Natural Science Subject for Grade VIII in Kota Komba East Manggarai. It is a quantitative research, using a quasi-experiment method. The variables are: (1) The Independent Variable that is the learning design model named Cooperative Group Investigation; and (2) The Dependent Variable consist of the learning activity and the result of the learning. The technique of data collection exerts the achievement test. The sample of the research applies to 88 students in Grade VIII of Junior High School (SMP) during the 2018-2019 academic years in Kota Komba East of Manggarai. This research is carried out in four groups, namely: (1) Grade VIII of SMP Satu Atap Pedak, is as a control group; (2) Grade VIII of SMPN 8 is as a control group; (3) Grade VIII of SMP Pancasila Mukun, is as an experimental group; (4) Grade VIII of SMPN 3 is as an experimental group. Hypothesis testing is using analysis of variance (ANOVA) with the aid of SPSS 22. The result of the analysis concludes that the Cooperative Group Investigation gives a significant influence on student's learning, as it represents in the value of F $19,696>0,000$ with the degree of sig on $0.05(5 \%)$.
\end{abstract}

This is an open access article under the CC-BY-SA license.

\section{INTRODUCTION}

In general, Natural Science Subject is one of the difficult subjects for students since it is not enough to learn the theories, but it needs much practice in its learning so that the student does not only know the fact but also they can apply the knowledge into the daily activities. In the learning of Science, the student needs to have in their pocket the basic skills and the integrated skills. The basic skills consist of the skill of observation, classify, measuring, communicating and prediction. Whereas the integrated skills can formulate hypotheses, variable control, problems, and interpret data (Suhardi, 2012). However, its implementation in the school nowadays tends to be theoretical only by applying the traditional learning method, lecture-based.

Education Act of the year 2003 number 20, confirmed that Education aims to develop the abilities, characters, along with culture and civilization of the nation to create a man of faith, devoted to the Almighty God, noble, healthy, knowledgeable, skillful, creative, independent, democratic, and responsible. In conformity with it, the role of the teacher is absolutely important in making the situation and condition of learning in order to prioritize the thought process of the student, recognition and acknowledgement of the role of the student, acceptance of individual differences of the student in the progress of their self development (Trianto, 2007).

Based on the initial observation, the Learning Planning Assessment Instrument (IPPP) was applied to observe the process of learning in Natural Science Subject for Grade VIII in SMPN 3 Kota Komba. Then it was known that the Learning Process Planning (RPP) which was made by the teacher of Natural Science Subject in the lesson of Human Respiration, used Discovery Learning. However, instead of applying it to teach the student, the teacher used the traditional learning method. In the Aftermath, the average value of final examination in the 2nd semester during the 2017-2018 academic years obtained the lower grade comparing to other senior high 
school (SMP), that is SMPN 3 Kota Komba $(70,7)$, SMPN 8 Kota Komba $(71,1)$, SMP Pancasila Mukun $(73,6)$, and SMP Satu Atap Pedak (70,2). In other words, the student lost out the minimum standard competence of Natural Science Subject (75).

Various factors influence the lack of understanding of students in studying Natural Science Subject, such as applying inappropriate learning method either to the purpose of the study or the lesson characteristic. The great learning strategies cover the whole part of the lesson, the procedure, and the stage of learning activities for the teacher to directing the student to achieve certain learning goals (Sanjaya Winna,2008).

In the application of the traditional learning method, the condition of the Group prone to be teacher-centered. The teacher deliver monotonous lesson so the student have no opportunities in expressing their ideas even their opinions. Nevertheless, the teacher still tend to choose and defend the traditional learning method in teaching.

According to decree of minister of education and culture year 2007 number 41 , the excellent process of teaching and learning is through the use of proper learning method to achieve the lesson goals, the characteristic of student, provided features and competencies mastery. The proper process of learning in elementary and junior high school should be conducted interactively, inspiring, challenging, pleasing and motivating the student to be actively and independently act upon their talent, interest, physical and psychological development.

The student can be said completely active in the learning activities if They will have : (1) Observating, that is paying attention to the delivered information and fastening eyes on the stages of lesson presentation; (2) Speaking, that is discussing with others about the lesson, interacting to the teacher, and actively expressing ideas; (3) Listening, that is giving an ear to the lesson presentation and understanding the conversations during the Group; (4) Writing, that is taking notes to the process of Q\&A, summarizing the lesson and making the report; (5) Drawing, that is making graphics, pattern or chart and also diagrams; (6) Practicing, that is performing in front of the Group, doing experiment, playing the roles, and demonstrating skills; (7) Mentally activities, that is able to answer, analyse the factors, solve the problem, make decision; (8) Emosionally activities, that is taking upon to express ideas, bravely to refute argument, having courage to answer the questions; so that influencing the learning result (Dieric dalam Hamalik, 2009).

The learning result in bulk large in seeing the alteration during the learning process. The change in the attitude means that there is also an advance in student's ways and means to reach the goals through many learning activities. It is principally the change of behavior as the result of the learning process. The change can be seen through the knowledge possessed, comprehension, skills, and attitude which usually includes the domain of cognitive, affective and psychomotor (Husama 2014).
The learning process both in the school and out of the school, produces the three forms of skills, that is cognitive, affective and psychomotor (Arends, 2007).

According to the objectives of the Human Respiration lesson, the student is expected to work in a group to identify and analyze the organ, comprehend the mechanism and explain how to maintain respiration. It needs a suitable learning method. The characteristic of the student Grade VIII is in the range of age 12 to 14 years old, the earlier period of adolescent. In this early days, there are many changes that they experienced, for example, their feeling and emotions are more sensitive, their ability of thinking start to be complete, critical and able to make abstract. The relation with others of the same age is important for them to the development of personal and social (Jeanne, 2008).

The previous view is absolutely in line with the view of Piaget in Majid's, that is the knowledge is build inside the thought of the student, whereas the teacher only has the role as the provider of facilities. It is most appropriate to Cooperative learning method, in the type of Group Investigation or it can be said as Cooperative Group Investigation (Piagen in Majid, 2013). Therefore, the application of Cooperative Group Investigation is appropriate to them according to their characteristics, the lesson and the objectives.

The cooperative learning exists by the assumption that the learning process is not only originated from the teacher, but it can proceed against every student in which each of them can potentially reciprocate information to teach each other. Based on the previous research conducted by Lie, the teaching that is given by others of the same age, can give better learning rather than the teacher does (Anita Lie, 2003). There are many models of this learning, one of them is Group Investigation.

The Cooperative Group Investigation can be said as a learning method aimed to facilitate the student to choose the topic and the group of study, make the cooperative plan, carry out the research, prepare the final report, up to presenting and evaluating. This learning method is applied to the heterogeneous, in which combining the excellent, the average and the lower in a group to have a task in finding out the information about the chosen topic, making the cooperative plan, carrying out the research, preparing the presentation, presenting and evaluating what they have done (Robert Slavin,2013).

This research is limited to take gauge of cognitive matter. According to the problems represent above, the Cooperative Group Investigation is expected to affect the learning result of Natural Science Subject for Grade VIII in the Junior High School (SMP) in Kota Komba East Manggarai. The application of the suitable learning method which is determined from the objective, the lesson and the student, is supposed to be applied by the teacher to develop their student to be more confidence since each of them is given individual opportunity to have discussions with others in the Group. 


\section{METHODS}

\subsection{Researc Design}

The research applies a quantitative method. Sugyono states that quantitative data is presented in numbers so that the analysis will exert through statistics. The implementation of quantitative is supposed to make no subjectivity in the research. Quasi-experiment design is chosen since it is in accord with the variable of the research and the purpose of the study which is to find out the influence of independent variables on the dependent variable (Sugiyono, 2007). Besides, the research is such of social experiment so that it will be well-designed with Nonequivalent Control Group.

Table 1. Non-Equivalent Control Group Design Plan

\begin{tabular}{cccc}
\hline Group & Pre-test & Treatment & Post-test \\
\hline Experiment & 01 & $X$ & 02 \\
Experiment & 03 & $X$ & 04 \\
Control & 05 & - & 06 \\
Control & 07 & - & 08 \\
\hline
\end{tabular}

At the beginning of the research, it will be held a pre-test to the group of experiment and the group of control. Then, the first group will get a treatment, which is the implementation of the independent variable. And the last one will be left with the usual treatment or no implementation of the independent variable. After the treatment, both of the group will be given a post-test to find out the result of the given treatment.

\subsection{Research Population and Sample}

According to Sugiono (2012), Population is the generalization of object and subject with its certain quality and characteristic that can be studied and concluded. The population as used in the research is the student of junior high school (SMP) grade VIII in Kota Komba East Manggarai, that is SMPN 1, SMPN 2, SMPN 3, SMPN 4, SMPN 5, SMPN 6, SMPN 7, SMPN 8, SMP Pancasila Mukun, SMP Satu Atap Pedak.

The Sample is apart of the number and the characteristic of the population (Sugiyono, 2010:81). Inline with the chosen population above, the sample of this research is determined into the student of Grade VIII at SMPN 3, SMPN 8, SMP Pancasila Mukun, and SMP Satu Atap Pedak. Then, those are divided into experimental and control groups. SMPN 3 and SMPN 8 are determined to be the first group, and the last is the second group.

\subsection{Data Collection Technique}

The Technique to collect the data is one of the prominent matter in this research since the collected data will give the actual information needed for the realization of the research. The chosen technique in this research is Test. Sukardi (2007) states that the test is consist of a compilation of questions to the person and the answer will be represented in number to be processed statistically. The function of the test is to draw the respond of the subject under study, then it is systematically processed to get the conclusion which is the visible image of the subject behavior. Inline to Sukardi, Arikunto (2013) said that the test can be said as a tool with procedure, either to find out or measure something in such condition, using a given method and rules. Before the implementation, the test should be validated first to the appropriate expert to know the compatibility of its material to the syllabus and the instrument used in the research (Arifin, 2009). After the validation, it will be tested the reliability to know the consistency of the measurer for many times in a different time. The reliability of the instrument used in this research will be tested using the alpha Cronbach technique (Umar, 2003).

\subsection{Analysis Technique}

Quantitative Research can be analyzed using statistics (Sugyono, 2010). As mentioned in the research design about the variable used in the research, the suitable technique to analyze the research is regression analysis with the help of SPSS 22 .

There are three tests to be conducted in the research, those are: (1) Normality Test, to find out the normality of the data used; (2) Homogeneity Test, to find out the origin of the sample is homogenous or heterogeneous. The test uses One Way ANOVA Technique; (3) Hypothesis Test, to see the influence of independent variable $(\mathrm{X})$ to the dependent variable (Y1). It uses Analisis of Variance (ANOVA), or it can be said as $\mathrm{F}$. The nominal of $\mathrm{F}$ can be concluded as having significant effect if the table of $\mathrm{F}$ is smaller than the arithmetic of $\mathrm{F}\left(\mathrm{F}_{\text {table }}<\mathrm{F}_{\text {count }}\right)$ with significance degree is $0,05(\sigma=0,05)$.

The criteria for making decisions on hypotheses based on ANOVA test results are as follows: $\mathrm{H}_{0}=$ "Accepted" if " $\mathrm{F}_{\mathrm{h}}<\mathrm{F}_{\text {table", }}$, and $\mathrm{H}_{0}=$ "Rejected" if " $\mathrm{F}_{\mathrm{h}}<$ Ftable".

\section{RESULTS AND DISCUSSIONS}

\subsection{Results}

\subsubsection{Test material Validation}

Table 2. Validation Result of test material

\begin{tabular}{|c|c|c|c|}
\hline No. & Indicator & Score & Description \\
\hline 1 & $\begin{array}{l}\text { The compability with basic competence } \\
\text { and its indicator. }\end{array}$ & 4 & Excellent \\
\hline 2 & The accuracy of words or language & 4 & Excellent \\
\hline 3 & No double interpretation & 4 & Excellent \\
\hline \multirow[t]{3}{*}{4} & $\begin{array}{l}\text { The clarity of the explanation and the } \\
\text { question. }\end{array}$ & 4 & Excellent \\
\hline & Total & 16 & \\
\hline & Average & 4,0 & \\
\hline
\end{tabular}

Table 2 indicates that the question with the basic competence and its indicator is excellently compatible. In line with the accuracy of words and language used, the interpretation of the question, the explanation and the question, are estimated very good. 


\subsubsection{Test material Reliability}

Table 3. Reability Result of test material

\begin{tabular}{cc}
\hline Cronbach,s Alpha & N of Items \\
\hline 0,975 & 20 \\
\hline
\end{tabular}

The result of the reliability test as presented in the table above shows that the value of Cronbach,s Alpa is 0,975 which is bigger than 0,60 as the minimum value of the reliability. Thereby, the instrument of the test material is reliable and ready to be used in the analysis to test the research hypothesis.

After the test of validation and reliability, the normality test of learning result can be conducted. The type of SPSS 22 used is Sample Kolmogorov Smirnov. The following criteria is if the result of the calculation is bigger than 0.05 ( $\operatorname{sig}>0,05$ ), it means that the data is normal. The result will be explained in the following table.

\subsubsection{Normality Test of Learning Result}

Tabel 4. Normality Test for Learning Result of Control Group SMP Satu Atap Pedak One-Sample Kolmogorov-Smirnov Test

\begin{tabular}{ccc}
\hline & Pre-test & Post-test \\
\hline N & 22 & 22 \\
Normal Mean & 66,14 & 73,64 \\
Std.Deviation & 14,052 & 10,256 \\
Most Extreme Differences A &, 195 &, 189 \\
Positive &, 195 &, 134 \\
Negative &,- 190 &,- 189 \\
Test Statistic &, 195 &, 189 \\
Asymp.Sig.(2-tailed) &, 029 &, 039 \\
\hline
\end{tabular}

The value of Kolmogorov-Smirnov for Learning Result of Control Group SMP Satu Atap Pedak in the table above shows that the pre-test score is 195 with significance point 0.029 and the post-test score is 189 with significance point 0.039. It means that the normality result for these control Group data, either the pre-test or the post-test, have a bigger significance point than 0.05 ( $\mathrm{sig}>0,05)$. It can be said that the learning result of this control Group is normally distributed.

Tabel 5. Normality Test for Learning Result of Control Group SMPN 8 Kota Komba. One-Sample Kolmogorov-Smirnov Test

\begin{tabular}{lcc}
\hline & Pre-test & Post-test \\
\hline $\mathrm{N}$ & 22 & 22 \\
Normal Mean & 72,95 & 75,23 \\
Std.Deviation Most Extreme Differences A & 8,261 & 9,191 \\
Positive & & \\
Negative &, 167 &, 174 \\
Test Statistic &, 167 &, 174 \\
Asymp.Sig.(2-tailed) &,- 167 &,- 174 \\
&, 167 &, 174 \\
&, 114 &, 080 \\
\hline
\end{tabular}

The result of Kolmogorov-Smirnov for Learning Result of Control Group SMPN 8 Kota Komba in the table above, indicates that the pre-test score is 167 with significance point 0.114 and the post-test score is 174 with significance point 0.080 which is bigger than 0,05 ( $\mathrm{sig}>0,05)$. This means that the learning result of this Control Group is normally distributed.

Tabel 6. Normality Test for Learning Result of Experiemental Group SMP Pancasila Mukun One-Sample Kolmogorov-Smirnov Test

\begin{tabular}{lcc}
\hline & Pre-test & Post-test \\
\hline $\mathrm{N}$ & 22 & 22 \\
Normal Mean & 75,23 & 88,86 \\
Std.Deviation & 12,954 & 7,060 \\
Most Extreme Differences Absolute & & \\
Positive &, 175 &, 163 \\
Negative &, 153 &, 163 \\
Test Statistic &,- 175 &,- 156 \\
Asymp.Sig.(2-tailed) &, 175 &, 163 \\
&, 079 &, 131
\end{tabular}

The result of Kolmogorov-Smirnov for Learning Result of Experimental Group SMP Pancasila Mukun in the table above indicates that the pre-test score is 175 with significance point 0.079 and the post-test score is 163 with significance point 0.131 which is bigger than 0,05 ( $\mathrm{sig}>$ 0,05). This means that the learning result of this Experimental Group is normally distributed.

Tabel 7. Normality Test for Learning Result of Experiement Group SMPN 3 Kota Komba One-Sample Kolmogorov-Smirnov Test

\begin{tabular}{lcc}
\hline & Pre-test & Post-test \\
\hline $\mathrm{N}$ & 22 & 22 \\
Normal Mean & 75,45 & 88,18 \\
Std.Deviation & 11,640 & 7,645 \\
Most Extreme Differences APositive & & \\
Negative &, 166 &, 161 \\
Test Statistic &, 115 &, 161 \\
Asymp.Sig.(2-tailed) &,- 166 &,- 121 \\
&, 166 &, 161 \\
&, 166 &, 141 \\
\hline
\end{tabular}

The result of Kolmogorov-Smirnov for Learning Result of Experimental Group SMPN 3 Kota Komba in the table above, indicates that the pre-test score is 166 with significance point 0.116 and the post-test score is 161 with significance point 0.141 which is bigger than 0,05 ( $\operatorname{sig}>$ 0,05). This means that the learning result of this Experimental Group is normally distributed.

\subsubsection{Homogeneity Test of Learning Result}

This homogeneity test applies the same SPSS 22 as the normality does, that is One Way ANOVA. The test result can be said as homogenous if its value is bigger than 0,05. This following is the result of the test to decide, it is homogenous or heterogenous. 
Tabel 8. Homogeneity Test of Learning Result Test of Homogeneity of Variances

\begin{tabular}{cccc}
\hline Levene Statistic & df1 & df2 & Sig. \\
\hline 1,600 & 3 & 84 &, 195 \\
\hline
\end{tabular}

The test result as presented in the table above indicates that the value of $\mathrm{F}$ is 1,600 with significance point 0,192 which is bigger than 0,05 ( $\operatorname{sig}>0,05)$. In other words, the test states that all variables between groups are homogenous.

\subsubsection{Hipotesis Test}

Tabel 9. Anova Learning Result ANOVA

\begin{tabular}{lccccc}
\hline & $\begin{array}{c}\text { Sum of } \\
\text { Squares }\end{array}$ & df & $\begin{array}{c}\text { Mean } \\
\text { Square }\end{array}$ & $F$ & Sig. \\
\hline Between & 4401,136 & 3 & 1467,045 & 19,696 &, 000 \\
Groups & 6256,818 & 84 & 74,486 & & \\
Within Groups & 10657,955 & & & & \\
Total & & 87 & & & \\
\hline
\end{tabular}

The result of ANOVA test to the learning result with significance point $=0,05$ and value of $\mathrm{F}=19,695$ with $\operatorname{sig}=$ 0,000 is far below 0,05 . It can be said that $\mathrm{H} 0$ is rejected, whereas $\mathrm{Ha}$ is accepted. In other words, the given treatment to the learning group, that is implementing Cooperative Group Investigation to the first group and not implementing it to the second one, make different result to each group even though in the beginning they have the same ability.

\subsection{Discussions}

Based on the learning result between the Control Group, they are Grade VIII SMP Satu Atap Pedak and Grade VIII SMPN 8 Kota Komba, and the Experimental Group, they are Grade VIII SMP Pancasila Mukun and Grade VIII SMPN 3 Kota Komba, can be seen that the learning result of the Experimental Group is highly increased than the Control Group. The average post-test scores in the Control group were as follows: Grade VIII SMP Satu Atap Pedak is 73,63 and Grade VIII SMPN 8 Kota Komba is 75,22 . Whereas the average post-test scores in the Experimental Group were as follows: Grade VIII SMP Pancasila Mukun is 84,77 and Grade VIII SMPN 3 Kota Komba 86,59. It can be said that after the implementation of Cooperative Group Investigation, there is a significant increase to the learning result, as it is seen in the hypothesis test which the Cooperative Group Investigation significance is stated giving influence to the learning result. Furthermore, the result of statistic analysis indicates that the value of $\mathrm{F}=19,696$ and sig $=$ 0,000 is far below 0,05 .

The learning result is educational assessment which is related to the progress of the student after involving in learning activities. Thus, the learning result could not be obtained without the assessment process to the result of the student's activity itself.

\section{CONCLUSION}

According to the research result and the data processing, it is known that the result of the ANOVA test with significance degree $\sigma=0,05$ is obtained $\mathrm{F}=19,696$ and sig $=0,000$, far below 0,05 , and the $\mathrm{H}_{0}$ is "Rejected" while the $\mathrm{Ha}$ is "Accepted" means that the Cooperative Group Investigation significantly gives different learning result comparing to the conventional learning design model. Thus it can be concluded that the implementation of Cooperative Group Investigation influences student's learning result in Natural Science Subject for junior high school (SMP) Grade VIII in Kota Komba East Manggarai.

\section{REFERENCES}

Arends, Richard I. (2007). Learning to Teach. New York: Mc Graw-Hill Book Company.

Anita Lie. (2003). Cooperatif Learning: Mempraktekkan Cooperatif Learning di Ruang-Ruang Kelas. Jakarta: Gramedia.

Arifin, Zainal. (2009). Evaluasi Pembelajaran. PT. Remaja Rosdakarya: Bandung

Trianto. (2007). Model Pembelajaran Terpadu. Jakarta: Perpustakaan Nasional.

Permendiknas No 41 Tahun 2007 tentang Standar Proses Untuk Satuan Pendidikan Dasar dan Menengah.

Husamah. (2014). Pembelajaran Bauran: Blended Learning. Jakarta: Prestas Pustaka Raya

Hamalik, Oemar, (2010). Proses Belajar Mengajar. Jakarta: PT Bumi Aksara

Jeanne Ellis. (2008). Psikologi Pendidikan Membantu Siswa Tumbuh Dan Berkembang. Edisi Keenam Jilid 2. Jakarta: Erlangga.

Majid Abdul, (2013). Strategi Pembelajaran. Bandung. PT Remaja Rosdakarya

Anita Lie. (2003). Cooperatif Learning: Mempraktekkan Cooperatif Learning di Ruang-Ruang Kelas. Jakarta: Gramedia.

Robert. E Slavin. (2010). Cooperative Learning Teori, Riset dan Praktik. Bandung: Nusa Media

Sanjaya winna, (2008). Strategi Pembelajaran Berorientasi Standart Proses Pendidikan. Jakarta: Kencana Prenaga Media Group

Sugiyono. (2007). Metode Penelitian Kombinasi (Mixed Methods). Bandung: Alfabeta.

Sugiyono. (2010). Metode Penelitian Kuantitatif Kualitatif dan R \& D. Bandung: Alfabeta.

Sukardi. (2007). Metodologi Penelitian Pendidikan Kompetensi dan Praktiknya. Jakarta: Bumi Aksa.

Suhardi. (2012). Pengembangan Sumber Belajar Biologi. Yogyakarta : UNY Press

Suharsimi, Arikunto. (2013). Prosedur Penelitian Suatu Pendekatan Praktik. Rineka Cipta: Jakarta.

Umar, Husein. (2003). Riset Pemasaran dan Perilaku Konsumen. Jakarta: Gramedia Pustaka Utama. 